\title{
Seasonal influence on sperm parameters, scrotal measurements, and serum testosterone in Ouled Djellal breed rams in Algeria
}

\author{
S. Belkadi, B. Safsaf, N. Heleili, M. Tlidjane, L. Belkacem and Y. Oucheriah \\ Department of Veterinary Science, Laboratory ESPA, Veterinary and Agricultural Sciences Institute, Hadj Lakhdar \\ University, Batna - 05000, Algeria. \\ Corresponding author: S. Belkadi, e-mail: souhilabelkadi@gmail.com \\ Co-authors: BS: saf2_b@yahoo.fr, NH: hnouz74@gmail.com, MT: ayathir@gmail.com, LB: Ibelkacm@yahoo.fr, \\ YO: yasmine_oucheriah@yahoo.com \\ Received: 16-07-2017, Accepted: 20-11-2017, Published online: 21-12-2017
}

doi: 10.14202/vetworld.2017.1486-1492 How to cite this article: Belkadi S, Safsaf B, Heleili N, Tlidjane M, Belkacem L, Oucheriah Y (2017) Seasonal influence on sperm parameters, scrotal measurements, and serum testosterone in Ouled Djellal breed rams in Algeria, Veterinary World, 10(12): 1486-1492.

\begin{abstract}
Aim: This study was conducted to determine the effect of seasonal variations on testosterone serum concentration, body weight, scrotal circumference, and some sperm parameters in rams living in a semi-arid region of eastern part of Algeria.

Materials and Methods: Blood samples were taken monthly from eight Ouled Djellal rams, aged between 3 and 4 years, in the Technical Institute of Breeding "ITELV" located at Ain M'lila City. Sperm were collected by an electro-ejaculator once a month for 1 year (spring, summer, autumn, and winter: 3 times/season).

Results: Mean values of volume, mass motility, live sperm, and scrotal circumference were higher during spring ( $\mathrm{p}<0.05$ ) with $1.23 \pm 0.26 \mathrm{~mL}, 3.39 \pm 1.07,79.16 \pm 15.82 \%$, and $36.29 \pm 1.91 \mathrm{~cm}$, respectively; whereas, the sperm concentration was higher during autumn with $1.19 \pm 0.56 \times 10^{9} \mathrm{spz} / \mathrm{ml}$ compared to $0.46 \pm 0.13 \times 10^{9} \mathrm{spz} / \mathrm{mL}$ to spring. The season influenced significantly the percentage of abnormal sperm $(p<0.05)$, especially during winter $(6.47 \pm 2.12 \%)$, but had no influence on the weight of rams. Seasonal hormonal activity was high with $4.89 \pm 2.06 \mathrm{ng} / \mathrm{mL}$ and $3.09 \pm 1.35 \mathrm{ng} / \mathrm{mL}$ of testosterone in mating seasons (spring and autumn, respectively), knowing that the sexual season is not marked too much in these latitude.

Conclusion: We can conclude that testosterone concentration is strongly correlated with the scrotal circumference and that the season has a significant influence on spermatic parameters, and that despite the large variations in sperm production, the rams can be used throughout the year.
\end{abstract}

Keywords: scrotal circumference, season, semi-arid area, spermatozoon, testosterone, weight.

\section{Introduction}

Sheep farming in Algeria constitutes $50 \%$ of the agricultural gross domestic product and the sheep number has increased from 17.5 to 26.6 million head, with an average annual increase of $4.4 \%$ over the 10-year period (2003-2013) [1]. The sheep raising is concentrated in the steppe and constitutes a large animal resource of the country. This breed tends to dominate other blood, improving its fertility to increase livestock productivity and reproductive efficiency [2]. The mutton meat is the most favorable red meat for consumption and is the favorite in religious and traditional festivals.

Eight major breeds have been identified so far. Some of these breeds show strong adaptation capabilities to harsh environmental conditions (such as water and/or food scarcity and high temperatures). Among them, one breed, the Ouled Djellal (OD) also known as the great white Arabian breed, bred in the arid and

Copyright: Belkadi, et al. Open Access. This article is distributed under the terms of the Creative Commons Attribution 4.0 International License (http://creativecommons.org/licenses/ by/4.0/), which permits unrestricted use, distribution, and reproduction in any medium, provided you give appropriate credit to the original author(s) and the source, provide a link to the Creative Commons license, and indicate if changes were made. The Creative Commons Public Domain Dedication waiver (http:// creativecommons.org/publicdomain/zero/1.0/) applies to the data made available in this article, unless otherwise stated. semi-arid regions and subjected to clear preference of the farmers [3]. The race OD supplants and jeopardizes the existence of other ovine Algerian breeds due to its high zootechnical potential [4]. Moreover, that obvious prevalence (58\% of the Algerian sheep) on the economical market induces a very sensitive situation for the other breeds, especially because some of them are submitted to uncontrolled crossbreeding with the favored breed and/or to real marginalization [5].

Ram's sexual behavior can be influenced by many factors, including season of the year, genetics, breed differences, hormonal influence, post-weaning management, temperature, and nutrition. However, the photoperiod is the main environmental factor affecting sheep reproduction [6]. Thus, in subtropical areas, many goat and sheep breeds express seasonal variation of their sexual activity. This is similar to that observed in temperate zones, except in terms of duration of sexual activity expression due to the amplitude of photoperiod variation [7]. During ram's life, body weight, scrotal circumference, and testosterone levels change under the influence of several internal and external factors. Data on ram's reproduction reveal a complex relationship between the development of the neuroendocrine system, the concentration of testosterone, the development of certain parts of body, and sexual maturation [8]. Therefore, knowledge of the 
quality of sperm can influence reproductive factors in order to improve genetically the breed and increase the numerical productivity of the herd [9]. Seasonal variation in mammals' breeding is an adaptation to the annual environmental changes [10]; therefore, they are an important factor influencing the quantity and quality of sperm. Thus, in temperate regions, sheep have a clear seasonal sexual activity; where males exhibit changes in behavior, testicular weight, and qualitative and quantitative sperm production coinciding with decreased day length [11]. Testosterone plays a central role in the control of spermatogenesis from the testicular stage (differentiation of spermatogonia to spermatids) and decreases germ cell apoptosis [12], in the development and maintenance of sexual behavior in rams [13]. Blood levels vary according to race, age, nutrition, and season [14].

The present study aimed to evaluate the influence of the season on spermatozoa and blood testosterone concentration in OD rams in semi-arid zones. In order to select the best spawners at our insemination centers during or outside the mating season, it is useful to have specific and objective information about testicular development, sperm characteristics, and hormonal status.

\section{Materials and Methods}

\section{Ethical approval}

The blood samples were collected from the animals for serum extraction. The ethical considerations in accordance to the Institute Animal Ethics Committee related to animal handling were observed to ensure no pain to animal during sampling.

\section{Experimental location and climate}

The study was performed at ITELV-Ain M'lila (Technical Institute of Breeding), a semi-arid region in north steppic region of eastern part of Algeria at $775 \mathrm{~m}$ of altitude, $36^{\circ} 2^{\prime} 13^{\prime \prime}$ North of latitude and 6 $6^{\circ} 34^{\prime} 33^{\prime \prime}$ East of longitude. Each season lasts 3 months. The area is characterized by very cold winters with a minimum between $1^{\circ} \mathrm{C}$ and $5^{\circ} \mathrm{C}$ in January and very hot and dry summers with temperatures between $33^{\circ} \mathrm{C}$ and $40^{\circ} \mathrm{C}$ recorded in August.

\section{Animals}

Eight white OD rams, aged between 3 and 4 years, were used at the Technical Institute of Breeding (ITELV). At the center, the ram effect is the practice used for reproduction. Two months before the fight, these rams are removed from the herd and reintroduced at both breeding periods. Two days before harvesting of blood samples and sperm collection, the rams are removed from the herd.

These rams were dewormed once a year and received a diet consisting of barley straw or wheat, alfalfa hay, and concentrate. The water was ad-libitum. The mean score of the rams' body condition varied between 2.5 and 3.0 (scale $=0-5$ ) according to Dedieu et al's. method [15]. The mating is carried out in two periods, one in spring (April-May) and the other in autumn (October-November).

\section{Blood samples for hormonal dosage}

Blood samples were taken monthly from the jugular vein of each ram for 1 year. The blood was immediately centrifuged and the serum obtained was frozen at $-20^{\circ} \mathrm{C}$ until testosterone was assayed. The serum testosterone concentration was determined using Enzyme Immunoassay kits (ST AIA - PACK Testosterone for quantitative measurement of testosterone in serum on TOSOH AIA System Analyzers).

\section{Weight and testicular weight measurement}

A weighing balance scale was used for weighing and a zootechnical tape measure was used for measuring scrotal circumference at the largest diameter of the scrotum.

\section{Sperm collection and evaluation}

Semen was collected with an electro-ejaculator from all the rams. The volume was read by means of a graduated tube; the concentration of $10^{9} / \mathrm{ml}$ was determined by counting on a Malassez slide and the mass motility was subjectively evaluated by examining an undiluted and colored sperm drop under a microscope equipped with a heating platform. Motility was assessed at magnification $10 \times$ to assess the intensity of the waves formed by sperm movements; a score ranging from 0 to 5 was attributed [16]. However, the vitality was assessed by counting after Eosin-Nigrosin staining, to determine the percentage of live (Eosin negative) spermatozoa.

\section{Statistical analysis}

The results are presented with standard deviation. The analysis of the ANOVA variance was used to determine seasonal variations in sperm parameters and testosteronemia, and measurements (weight and testicular) were performed using Graph Pad Prism 5.03. The differences detected were considered significant when $\mathrm{p}<0.05$.

\section{Results}

Seasonal variations in body weight and scrotal measurements

\section{Weight}

Table-1 shows that weight did not vary significantly $(\mathrm{p}>0.05)$ with maximum averages during spring $(94.71 \pm 3.79 \mathrm{~kg})$ and minimal during autumn (91.96 \pm 4.10$)$. Although we observe a little decrease, there was no significant change during the winter and summer $(93.46 \pm 5.82 \mathrm{~kg}$ and $92.45 \pm 2.79 \mathrm{~kg}$, respectively) (Table-1).

\section{Scrotal circumference}

Seasonal influence on scrotal circumference was statistically significant $(\mathrm{p}<0.05)$. The highest averages were recorded during spring $(36.3 \pm 1.9 \mathrm{~cm})$ and in autumn during breeding months, while the lowest averages were observed during summer $(33.3 \pm 1.9 \mathrm{~cm})$ (Table-1). 


\section{Seasonal variations of serum testosterone}

Statistical analysis showed that testosterone serum levels were significantly affected by breeding months. Thus, we observed a significant difference $(\mathrm{p}<0.05)$ compared to spring versus summer and winter versus spring. As for seasonal averages, the highest values were observed in spring and autumn with $4.89 \pm 2.06 \mathrm{ng} / \mathrm{mL}$ and $3.09 \pm 1.35 \mathrm{ng} / \mathrm{mL}$, respectively, coinciding with the periods of maximum sexual activity. However, there was no correlation between testosterone levels and spermatic parameters (Table-1).

\section{Seasonal variations of spermatic parameters}

\section{Volume}

Season influenced significantly the volume of collected sperm $(\mathrm{p}<0.05)$; sperm production was maximal during spring $(1.23 \pm 0.26 \mathrm{~mL})$, while the lowest volume was obtained in winter $(0.94 \pm 0.11)$ (Table-2).

\section{Massal motility}

Results indicated that massal motility was not significantly $(\mathrm{p}>0.05)$ affected by season (Table-2). However, the higher average value was observed in spring (3.39 \pm 1.07$)$, which decreased in summer, and then reached a new peak in autumn $(2.83 \pm 1.33)$ and decreased again during winter.

\section{Sperm concentration}

The mean averages showed significant difference $(\mathrm{p}<0.001)$, with a greater sperm concentration in autumn $\left(1.19 \pm 0.56 \times 10^{9} \mathrm{spz} / \mathrm{mL}\right)$ and low concentration $\left(0.46 \pm 0.13 \times 10^{9} \mathrm{spz} / \mathrm{mL}\right)$ in spring (Table-2).

\section{Live spermatozoa}

Results obtained showed a significant influence of season on the percentage of live spermatozoa $(\mathrm{p}<0.05)$. The maximum averages $(79.16 \pm 15.82)$ were observed during spring, which corresponds to the mating period, while lowest was noted during summer.

\section{Abnormal sperm}

Monthly average results of the anomaly rate showed a rise from the end of autumn to the end of winter with significant rate during the winter $(6.47 \pm 2.12 \%)$ followed by a remarkable decrease with a minimal average recorded during the summer $(2.47 \pm 0.88 \%)$ (Table-2).

\section{Discussion}

Several studies have demonstrated that season has an influence on ram's reproductive characteristics $[17,18]$. They reported that the standard method of evaluating the fertility of male breeding is the examination of sperm production [19]. We observed no significant difference $(p>0.05)$ and no seasonal effect on the ram weight; this result could be explained by the fact that these rams are adults and raised under good conditions at the breeding institute. Kafi et al. [17] and Kridli et al. [6] reported that body weight was not affected by seasonal variation on Persian karakul rams while Avdi et al. [20] and Boucif et al. [21] observed seasonal changes.

For scrotal circumference, Maksimovic et al. [8], Abba et al. [22], and Ghorbankhani et al. [23] have shown that testicular size is often used to evaluate ram's fertility and that testicular morphometry was considered as the predictor of sperm production. Similarly, Belkhiri et al. [24] reported that the measurement of scrotal circumference in OD rams could be used in breeding centers to select suitable breeding male for artificial breeding purpose. Thus, the highest

Table-1: Seasonal variations in body weight, scrotal circumference, and serum testosterone. Pearson's correlation between scrotal circumference and testosterone.

\begin{tabular}{lccc}
\hline Periods & Weight $(\mathbf{k g})$ & Scrotal circumference $(\mathbf{c m})$ & Testosterone $\mathbf{( n g / m L )}$ \\
\hline Winter $(n=24)$ & $93.5 \pm 5.8$ & $34.0 \pm 2.1$ & $2.42 \pm 1.59$ \\
Spring $(n=24)$ & $94.7 \pm 3.8$ & $36.3 \pm 1.9$ & $4.89 \pm 2.06$ \\
Summer $(n=24)$ & $92.5 \pm 2.8$ & $33.3 \pm 1.9$ & $2.21 \pm 1.66$ \\
Autumn $(n=24)$ & $92.0 \pm 4.1$ & $34.9 \pm 2.1$ & $3.09 \pm 1.35$ \\
Statistical significance & NS & $a *$ & a* ${ }^{*}$ \\
\hline
\end{tabular}

aSpring versus summer; ${ }^{b}$ Winter versus spring; * $\mathrm{p}<0.05$

Table-2: Seasonal variations of spermatic parameters (volume, massal motility, sperm concentration, live and abnormal spermatozoa).

\begin{tabular}{|c|c|c|c|c|c|}
\hline Periods & Volume (mL) & Massal motility & $\begin{array}{c}\text { Sperm } \\
\text { concentration }\left(\times 10^{9} / \mathrm{mL}\right)\end{array}$ & $\begin{array}{c}\text { Live } \\
\text { spermatozoa (\%) }\end{array}$ & $\begin{array}{c}\text { Abnormal } \\
\text { spermatozoa (\%) }\end{array}$ \\
\hline Winter $(n=23)$ & $0.94 \pm 0.11$ & $2.62 \pm 1.00$ & $0.59 \pm 0.25$ & $74.4 \pm 10.1$ & $6.47 \pm 2.12$ \\
\hline Spring $(n=24)$ & $1.23 \pm 0.26$ & $3.39 \pm 1.07$ & $0.46 \pm 0.13$ & $79.2 \pm 15.8$ & $3.71 \pm 1.71$ \\
\hline Summer $(n=24)$ & $1.14 \pm 0.20$ & $2.16 \pm 0.84$ & $0.54 \pm 0.26$ & $58.3 \pm 14.9$ & $2.47 \pm 0.88$ \\
\hline Autumn $(n=24)$ & $1.09 \pm 0.18$ & $2.83 \pm 1.33$ & $0.96 \pm 0.27$ & $80.0 \pm 9.03$ & $4.04 \pm 1.83$ \\
\hline $\begin{array}{l}\text { Statistical } \\
\text { significance }\end{array}$ & $b^{*}$ & & $\mathrm{c}^{* *} ; \mathrm{d}^{* * *} ; \mathrm{e}^{*}$ & $a * ; c^{*}$ & $b * ; f * *$ \\
\hline
\end{tabular}

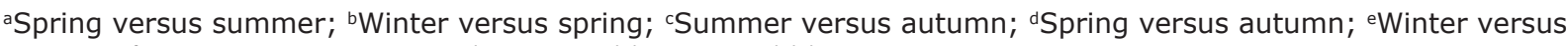
autumn; fWinter versus summer. $* p<0.05 ; * * p<0.01 ; * * * p<0.001$ 
measurements observed in spring and autumn season coincide with the periods of breeding practiced in this farm, where the increase in testicular volume is associated with an increase of sperm production. Authors reported also that, during the resumption of sexual activity season, there is a time lag in the resumption of this activity, which begins a month to a month and a half earlier in males than in females [25]. Our results are almost equivalent to those reported by Allaoui et al. [26] on adult rams. The lowest average was observed in summer, conversely to the observation of Boucif et al. [21] during winter in western part of Algeria over rams OD. On Lacune rams at Brazil [27] a significant difference was found $(\mathrm{p}<0.05)$ between winter $(31.0 \pm 3.4 \mathrm{~cm})$ and spring $(34.1 \pm 2.5 \mathrm{~cm})$, and no significant difference between the other seasons, which is consistent with our results. The peak of measurements observed in September is in agreement with the observations of Ghorbankhani et al. [23] in Iran in Sinjabi rams and Kafi et al. [17] in Persian Karakul rams.

The observed morphometric variations correlated with serum testosterone levels (Table-3), which follow the same seasonal pattern. Since testosterone is the hormone that controls testicular,

Table-3: Average number of live spermatozoa and sperm doses usable for AI $\left(400 \times 10^{6} \mathrm{spz}\right.$ live $)$ obtained per ram per collection.

\begin{tabular}{lcc}
\hline Periods & $\begin{array}{c}\text { Number of live } \\
\text { spermatozoa } \\
\text { (millions) per } \\
\text { collection }\end{array}$ & $\begin{array}{c}\text { Sperm doses } \\
\text { usable for AI } \\
\text { per collection }\end{array}$ \\
\hline Winter $(\mathrm{n}=24)$ & $413 \pm 154$ & $1.03 \pm 0.38$ \\
Spring $(\mathrm{n}=24)$ & $448 \pm 140$ & $1.12 \pm 0.35$ \\
Summer $(\mathrm{n}=24)$ & $359 \pm 215$ & $0.90 \pm 0.54$ \\
Autumn $(\mathrm{n}=24)$ & $837 \pm 325$ & $2.09 \pm 0.81$ \\
Statistical & $a * * * ; b * * ; c * *$ & $a * * * ; b * * \mathrm{c}^{* *}$ \\
significance & & \\
\hline
\end{tabular}

${ }^{a}$ winter versus autumn, bspring versus autumn, ${ }^{\text {csummer }}$ versus autumn. $* * \mathrm{p}<0.01 ; * * * \mathrm{p}<0.001$. AI $=$ Artificial insemination epididymal, and accessory glands' activities, several authors argue that testosteronemia is a good marker of quantitative and qualitative production of sheep sperm [28-31]. Darbeïda et al. [32], who worked on OD rams, found that testosterone reached a peak in summer and a low rate in winter; while Loubser et al. [33] found that the peak of testosterone blood concentration $(10.9 \mathrm{ng} / \mathrm{mL})$ in the Angora breed reached at the beginning of March. Our results seem to be in agreement with those of Benia et al. [34] who found that testosterone concentrations are maximal during spring and autumn months, and that OD rams showed continuous spermatogenetic activity during all seasons. In addition, serum testosterone levels were low during July where the temperature was very high on the day of collection. This is in agreement with the results obtained by Maurya et al. [35] in Malpura rams subjected to high temperatures $\left(42^{\circ} \mathrm{C}\right.$ and $55 \%$ of relative humidity) for $6 \mathrm{~h}$ per day during 10-16 h. It was also reported in bulls and boars that testosteronemia was found to decrease during high heat, but tends to recover if heat stress lasts more than 2 weeks [36].

The values recorded for the ejaculated volume were lower in winter as reported by Boucif et al. [21] and Pourseif et al. [37]. In addition, an increase of volume was noted at the end of June to the end of September and a decrease toward the end of October. This decrease is being maintained until the end of February to increase gradually and reach a new peak in March $(1.35 \pm 0.15 \mathrm{~mL})$. It was lower than that of $1.99 \mathrm{~mL}$ recorded using artificial vagina by Aissaoui et al. [38]. The increase in sperm volume from the end of winter to its peak in spring is in agreement with Kafi et al's. [17] results. On the other hand, Aissaoui et al. [38] showed that the quantity of ejaculated semen reaches maximum values in June and seems to evolve with the daily illumination duration.

The fluctuations of mass motility were not really affected by the photoperiod as shown by Colas [39] and Aller et al. [40]. We note that motility follows the

Table-4: Pearson's correlation between testosterone, scrotal circumference, and sperm parameters.

\begin{tabular}{|c|c|c|c|c|c|c|c|c|}
\hline Testosterone & $\begin{array}{l}\text { Testosterone } \\
(\mathrm{ng} / \mathrm{mL})\end{array}$ & $\begin{array}{l}\text { Scrotal } \\
\text { circumference } \\
(\mathbf{c m})\end{array}$ & $\begin{array}{l}\text { Weight } \\
\text { (kg) }\end{array}$ & $\begin{array}{l}\text { Volume } \\
(\mathrm{mL})\end{array}$ & $\begin{array}{l}\text { Massal } \\
\text { motility }\end{array}$ & $\begin{array}{c}\text { Sperm } \\
\text { concentration } \\
\left(\times 10^{9} / \mathrm{ml}\right)\end{array}$ & $\begin{array}{c}\text { Live } \\
\text { spermatozoa } \\
(\%)\end{array}$ & $\begin{array}{c}\text { Abnormal } \\
\text { spermatozoa } \\
(\%)\end{array}$ \\
\hline $\begin{array}{l}\text { Scrotal } \\
\text { circumference } \\
(\mathrm{cm})\end{array}$ & 0.974 & & & & & & & \\
\hline Weight (kg) & 0.724 & 0.639 & & & & & & \\
\hline Volume (mL) & 0.690 & 0.563 & 0.311 & & & & & \\
\hline Massal motility & 0.943 & 0.986 & 0.684 & 0.428 & & & & \\
\hline $\begin{array}{l}\text { Sperm } \\
\text { concentration } \\
\left(\times 10^{9} / \mathrm{ml}\right)\end{array}$ & -0.249 & -0.062 & -0.753 & -0.280 & -0.071 & & & \\
\hline $\begin{array}{l}\text { Live } \\
\text { spermatozoa } \\
(\%)\end{array}$ & 0.647 & 0.798 & 0.345 & -0.001 & 0.856 & 0.357 & & \\
\hline $\begin{array}{l}\text { Abnormal } \\
\text { spermatozoa } \\
(\%)\end{array}$ & -0.143 & -0.007 & 0.217 & -0.811 & 0.155 & 0.086 & 0.471 & \\
\hline
\end{tabular}


same trend as that of testosterone. However, it seems to be affected by the high temperatures because we noted very low values in July (where the ambient temperature reached $47^{\circ} \mathrm{C}$ ), which is in agreement with the finding of Ghozlane et al. [41]. Kafi et al. [17] have demonstrated in a study on Iran Karakul breed rams that high temperatures do not affect mass motility of semen and have concluded that higher sperm quality is obtained toward the end of summer.

Sperm concentration is the most variable parameter (more than double in spring to autumn). Our results are comparable to those found by Deldar et al. [42], Zamiri et al. [18], and Moghaddam et al. [43], with maximum values in autumn and decreased ones in winter. Similar observations have been reported in the Ile-de-France breed, where Colas [44] noted that sperm-fertilizing power is significantly lower in spring (March-April) than in autumn (September) in the adult ram.

Percentage of live sperm is significantly affected by the season, the highest mean value is recorded in autumn; while the lowest value is in summer. It should be noted that Pourseif et al. [37] observed the highest rate of sperm vitality from September to December, thus meeting the observations of Dufour et al. [45] and Moghaddam et al. [43], with higher values in autumn (October-November) than in spring. However, Kafi et al. [14] observed the highest rate in September $(97.6 \pm 13.1 \%)$ and the lowest one in January $(82.1 \pm 11.3 \%)$. Aller et al. [40] found no significant effect of season on live spermatozoa.

A significant effect of season on the percentage of abnormal spermatozoa, especially in winter, is noted, in comparison with low values recorded in spring and summer $(\mathrm{p}<0.05)$, which is in agreement with results obtained by Mandiki et al. [46]. The increased rate of sperm abnormalities can be explained by decreased serum testosterone concentration, reduced seminiferous tube diameter and spermatogenetic activity, or a maturation defect at the epididymal level [47]. The best indicator of seasonal effects on sperm quality is sperm abnormality, which is generally proportional to the fertility test [39]. Zamiri et al. [18] found that the rate of sperm abnormalities increased from January to March, with rates ranging from $7.5 \%$ to $14.2 \%$. The average morphological abnormalities of spermatozoa recorded during our experiment were $<15 \%$, percentage above which sperm is considered to be of poor quality [13].

Finally, the mean number of live spermatozoa per collection and thus the theoretical mean number of semen doses usable for artificial insemination (AI) obtained per male varied from simple to double between winter and autumn (Table-4).

\section{Conclusion}

The observed changes on sperm parameters during the period of reproduction indicated a relationship between serum testosterone massal motility and scrotal circumference. The best sperm was obtained during spring and autumn, coinciding with usual matting periods in our farms. Moreover, the average number of doses usable for AI tends to be higher in autumn and lower in summer and winter. Overall, our results illustrate that seasonal variations of sperm concentration do not prevent using OD breed rams throughout the year for collection of sperm to be used for AI.

\section{Authors' Contributions}

$\mathrm{SB}, \mathrm{BS}$, and $\mathrm{NH}$ designed the experiment protocol. SB and LB carried out the experiment work. SB, $\mathrm{BS}, \mathrm{NH}$, and MT were involved in data analysis and scientific discussion. $\mathrm{SB}, \mathrm{BS}, \mathrm{NH}, \mathrm{MT}, \mathrm{LB}$, and $\mathrm{YO}$ drafted and revised the paper. All authors read and approved the final manuscript.

\section{Acknowledgments}

The authors are thankful to the Director and staff of the Technical Institute of Breeding "ITELV" Ain M'lila for their kind cooperation and contribution to this study and Dr. Hafdi of the Medical Analysis Laboratory-Setif. This research received no specific grant from any funding agency in the public, commercial, or not-for-profit sectors.

\section{Competing Interests}

The authors declare that they have no competing interests.

\section{References}

1. MADR (Ministry of Agriculture and Rural Development), (2014) Agricultural Statistics (Areas and Productions Serie B). MADR (Ministry of Agriculture and Rural Development), Algiers.

2. Safsaf, B., Belkadi, S., Belkacem, L., Mamache, B. and Tlidjane M. (2015) Variations of motility and survival with storage time at $4^{\circ} \mathrm{C}$ of epididymal spermatozoa Ouled Djellal breed rams in Eastern Algeria. Vet. World, 8: 326-329.

3. Ministère de l'Aménagement du Territoire et de l'Environnement. (2014) $5^{\text {th }}$ Rapport National Sur la Mise en œuvre de la Convention sur la Diversité Biologique au Niveau National. Décembre 2014.

4. Saadi, M.A., Mefti, K.H., Benia, A.R., Bellala, R. and Kaidi, R. (2016) Effect of season and age rams breed "Ouled Djellal" on quality of their seed and reproduction in vivo. Int. J. Adv. Res. Biol. Sci., 3(5): 42-47.

5. Harkat, S., Laoun, S.A., Benali, R., Outayeb, D., Ferrouk, M., Maftah, A., DaSilva, A. and Lafri, M. (2015) Phenotypic characterization of the major sheep breed in Algeria. Rev. Méd. Vét., 166(5-6): 138-147.

6. Kridli, R.T., Abdullah, A.Y., Obeidat, B.S., Qudsieh, R.I., Titi, H.H. and Awawdeh, M.S. (2007) Seasonal variation in sexual performance of Awassi rams. Anim. Reprod., 4(1/2): $38-41$.

7. Hammoudi, S.M., Ait-Amrane, A., Belhamiti, T.B., Khiati, B., Niar, A. and Guetarni, D. (2010) Seasonal variations of sexual activity of local bucks in western Algeria. Afr. J. Biotechnol., 9(3): 362-368.

8. Maksimovic, N., Hristov, S., Stankovic, B., Petrovic, M.P., Mekic, C., Ruzic-Muslic, D. and Cardo-Petrovic, M. (2016) Investigation of serum testosterone level, scrotal circumference, body mass, semen characteristics, and their correlations in developing MIS lambs. Turk. J. Vet. Anim. Sci., 40: 53-59.

9. Haye, A., M'betiegue, C., Nazaire, L.G. and Tanon, B. 
(2004) Evaluation de la qualité du sperme du bélier de race Djallonké en région de svane humide de Côte d'Ivoire. Agron. Afr., 16(3): 37-46.

10. Bronson, F.H. (1989) Mammalian Reproductive Biology. The University of Chicago Press, Chicago and London. p1-325.

11. Sathe, S. and Shipley, C.F. (2014) Applied andrology in sheep, goats and selected cervids. In: Chenoweth, P.J. and Lorton, S.P., editors. Animal Andrology: Theories and Applications. CAB International, UK. p226-253.

12. Sang-Kon, L., Sungman, P. and Yoon-Won, K. (2016) The effects of extremely low-frequency magnetic fields on reproductive function in rodents. In Tech Open: Science/Open Mind World's Largest Science, Technology and Medicine Open Access Book. SAGE Publishing,Universidade de Tras-os-Montes e Alto Douro, Portugal.

13. Perkins, A. and Roselli, C.E. (2007) The ram as a model for behavioral neuroendocrinology. Horm. Behav., 52(1): 70-77.

14. Hassanin, S.H., Hussein, A.F., Khattab, Y.A. and Abdalla, M.A. (2013) Reproductive performance of ram under arid conditions. Life Sci. J., 10(4): 2596-2506.

15. Dedieu, B., Cournu, E. and Gibon, A. (1989) Notation de l'état corporel et système d'élevage ovin, diagnostic et conseils pour l'alimentation des troupeaux en Cévennes. INRA Prod. Anim., 2(2): 79-88.

16. Baril, G., Chemineau, P., Cognié, Y., Guerin, Y., Leboeuf, B., Orgeur, P. and Valet, J.C. (1993) Manuel de formation pour l'insémination artificielle chez les ovins et les caprins. Etude FAO Prod. Santé. Anim., 83: 231.

17. Kafi, M., Safdarian, M. and Hashemi, M. (2004) Seasonal variation in semen characteristics, scrotal circumference and libido of Persian Karakul rams. Small Rumin. Res., 53: 133-139.

18. Zamiri, M.J., Khalili, B., Jafaroghli, M. and Farshad, A. (2010) Seasonal variation in seminal parameters, testicular size and plasma testosterone concentration in Iranian Moghani rams. Small Rumin. Res., 94: 132-136.

19. Ax, R.L., Dally, M., Didion, B.A., Lenz, R.W., Love, C.C., Varner, D.D., Hafez, B. and Bellin, M.E. (2000) Semen evaluation. In: Hafez, B., and Hafez, E.S.E., editors. Reproduction in Farm Animals. $7^{\text {th }}$ ed. Lippincott Williams \& Wilkins. Philadelphia, PA. p365-375.

20. Avdi, M., Banos, G., Stefos, K. and Chemineau, P. (2004) Seasonal variation in testicular volume and sexual behavior of Chios and Serres rams. Theriogenology, 62: 275-282.

21. Boucif, A., Azzi, N., Tainturier, D. and Niar, A. (2007) Variations saisonnières des paramètres reproductifs chez les béliers de deux races locales algériennes. Renc. Rech. Ruminants, 14: 308.

22. Abba, Y. and Igbokwe, I.O. (2015) Testicular and related size evaluations in Nigerian sahel goats with optimal cauda epididymal sperm reserve. Vet. Med. Int., 2015: 5.

23. Ghorbankhani, F., Souri M., Moeinin, M.M. and Mirmahmoudi, R. (2015) Effect of nutritional state on semen characteristics, testicular size and serum testosterone concentration in Sinjabi ram lambs during the natural breeding season. Anim. Reprod. Sci., 153: 22-28.

24. Belkhiri, Y., Bouzebda-Afri, F., Bouzebda, Z. and Djaout A. (2017) Testicular morphometric measurements of Ouled Djellal lambs from birth to puberty. Glob. Vet., 18(2): 85-91.

25. Chalivoix, S. (2010) Transition Photopériodique et Plasticité Neuronale dans L'hypothalamus Ovin: Aspects Neuranatomiques et Fonctionnels. Thèse Doctorat - Université François Rabelais. Tours. p11.

26. Allaoui, A., Safsaf, B., Laghrour, W. and Tlidjane, M. (2014) Factors Affecting Scrotal Measurements and Weight of Ouled Djellal Rams in Eastern and South-Eastern Algeria. $4^{\text {th }}$ International Conference on Agriculture and

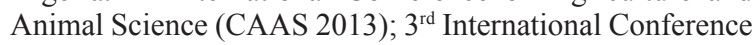

on Asia Agriculture and Animal (ICAAA 2013). APCBEE Procedia, 8: 260-265.

27. Oberst, E.R., Smirdele, W.A., Brito, M.A., Marschner, T.R., Ribeiro, L.A. and Mattos, R.C. (2011) Seasonal variation in semen quality of Lacune rams in Brazil. Braz. J. Vet. Res. Anim. Sci., Sào Paulo., 48(4): 319-324.

28. Issa, M., Yenikoye, A., Marichatou, H. and Banoin, M. (2001) Spermogramme de béliers peuls bicolores et touaregs: Influence du type génétique et de la saison. Rev. Elev. Méd. Vet. Pays Trop., 54(3-4): 269-275.

29. Kishk, W.H. (2008) Interrelationship between ram plasma testosterone level and some semen characteristics. SlovakJ. Anim. Sci., 41(2): 67-71.

30. Belkhiri, Y., Bouzebda-Afri, F., Bouzebda Z. and Mouffok, C. (2017) Age and season effects on sexual parameters in mature rams used in artificial insemination centre (Algeria). Glob. Vet., 18(1): 31-40.

31. Focșăneau, V., Bogdan, L., Andrei, S., Bogdan, S. and Petrean, A.B. (2014) Performance of some variables used as a procedure for estimating sexual capacity (fertility) of the ram. Bull. Univ. Agric. Sci. Vet. Med. Cluj-Napoca. Vet. Med., 71(1): 52-55.

32. Darbeïda, H. and Brudieu, R. (1980) Seasonal variations in plasma testosterone and dihydro - Testosterone levels and in metabolic clearance rate of testosterone in rams in Algeria. J. Reprod. Fertil., 59: 229-235.

33. Loubser, P.G., Van Nieker, C.H. and Botha L.J.J. (1983) Seasonal changes in sexual activity and semen quality in the Angora ram. 1. Libido and male hormone concentrations. South. Afr. Tyydskr. Veek., 13: 131-133.

34. Benia, A.R., Taibi, K., Ait-Amrane, A., Hammoudi, S.M. and Kaidi, R. (2013) Study of seasonal sexual activity variations in Algerian rams: Sexual behaviour, testosterone concentration control and environmental factors. Afr. J. Biotechnol., 12(41): 6042-6048.

35. Maurya, V.P., Sejian, V., Kumar, D. and Naqvi S.M.K. (2016) Impact of heat stress, nutritional restriction and combined stresses (heat and nutritional) on growth and reproductive performance of Malpura rams under semi-arid tropical environment. J. Anim. Physiol. Anim. Nutr., 100(5): 938-46.

36. Hansen, P.J. (2009) Effects of heat stress on mammalian reproduction-review. Phil. Trans. R. Soc. B., 364: 3341-3350.

37. Pourseif, M.M., Moghaddam, G.H., Rafat, S.A., Daghighkia A. and Pourseif, A. (2013) Photoperiod as a factor for studying fluctuations of seminal Traits during breeding and non-breeding season. Iran. J. Appl. Anim. Sci., 3(2): 313-321.

38. Aissaoui, C., Chibani, J. and Bouzebda, Z. (2004) Etude des variations de la production spermatique du bélier de race Ouled Djellal soumis à un régime pauvre. Renc. Rech. Ruminants, 11: 402.

39. Colas, G. (1980) Variations saisonnières de la qualité du sperme chez le bélier Ile-de-France. I- Etude de la morphologie cellulaire et de la motilité. Reprod. Nutr. Dév., 20(6): 1789-1799.

40. Aller, J.F., Aguilar, D., Vera, T., Almeida, G.P. and Alberio, R.H. (2012) Seasonal variation in sexual behavior, plasma testosterone and semen characteristics of Argentine Pampinta and Corriedale rams. Span. J. Agric. Res., 10(2): 345-3525.

41. Ghozlane, F., Ziki, B. and Yakhlef, H. (2005) Variations saisonnières des caractères quantitatifs du sperme de bélier de race Ouled Djellal. Renc. Rech. Ruminants, 12: 164.

42. Deldar, T.H., Zare, S.A., Moradi, S.M. and Shakeri, M. (2007) Monthly variation of plasma concentration of testosterone and thyroid hormones and reproductive characteristics in three breeds of Iranian fat-tailed rams throughout one year. Pak. J. Bio. Sci., 10: 3420-3424.

43. Moghaddam, G.H., Pourseif, M.M. and Rafat, S.A. (2012) 
Seasonal variation in semen quality and quantity traits of Iranian crossbred rams. Slovak J. Anim. Sci., 45(3): 67-75.

44. Colas, G. (1981) Variations saisonnières de la qualité du sperme chez le bélier Ile-de-France. II. Fécondance: Relation avec les critères qualitatifs observés in vitro. Reprod. Nutr. Dév., 21(3): 399-407.

45. Dufour, J.J., Fahmy, M.H. and Minvielle, F. (1984) Seasonal changes in breeding activity, testicular size, testosterone concentration and seminal characteristics in ram with long or short breeding season. J. Anim. Sci.,
58: 416-422.

46. Mandiki, S.N.M., Deriscke, G., Bister, J.L. and Paquay, R. (1998) Influence of season and age on sexual maturation parameters of Texel, Suffolk, and Ile-de-France rams. 1. Testicular size, semen quality and reproductive capacity. Small Rumin. Res., 28: 67-79.

47. Barkawi, A.H., Elsayed, E.H., Ashour, G. and Shehata, E. (2006) Seasonal variation in semen characteristics, hormonal profiles and testicular activity in zaraibi goats. Small Rumin. Res., 66: 209-213.

$* * * * * * * *$ 